\title{
Becoming American/Becoming New Yorkers: Immigrant Incorporation in a Majority Minority City
}

\section{Citation}

Kasinitz, Philip, John Mollenkopf, and Mary C. Waters. 2002. Becoming American/becoming New Yorkers: Immigrant incorporation in a majority minority city. The International Migration Review 36(4): 1020-1036

\section{Published Version}

http://www3.interscience.wiley.com/journal/119926494/abstract

\section{Permanent link}

http://nrs.harvard.edu/urn-3:HUL.InstRepos:3293008

\section{Terms of Use}

This article was downloaded from Harvard University's DASH repository, and is made available under the terms and conditions applicable to Other Posted Material, as set forth at http:// nrs.harvard.edu/urn-3:HUL.InstRepos:dash.current.terms-of-use\#LAA

\section{Share Your Story}

The Harvard community has made this article openly available.

Please share how this access benefits you. Submit a story.

Accessibility 


\section{Becoming American/Becoming New Yorkers: Immigrant Incorporation in a Majority Minority City}

Philip Kasinitz

Hunter College and Graduate Center, CUNY

John Mollenkopf

Graduate Center, CUNY

Mary C. Waters

Harvard University

Many observers have noted that immigrants to the United States are highly concentrated in the largest metropolitan areas of a relatively few states. Though immigrants diffused into many places that had previously seen relatively few immigrants during the $1990 \mathrm{~s}$, as of the 2000 census, 77 percent of the nation's 31.1 million foreign born residents still lived in six states - California, New York, Texas, Florida, New Jersey, and Illinois. According to the 2000 census, the two largest metropolitan areas, Los Angeles and New York, accounted for one third of all immigrants (http://www.census.gov/Press-Release/www/2002/demoprofiles. html). While immigrants moved into many new areas during the $1990 \mathrm{~s}$, making the challenge of incorporating their children a national issue, their concentration in our largest cities remained pronounced.

This article examines how immigrants are being incorporated into American society in gateway cities by examining second generation immigrants in New York City. In contrast to the prevailing theoretical approach, which views immigrants as seeking to find a favorable place along the racial continuum between a native white elite on the top and native nonwhite minorities on the bottom, we argue that second generation experiences in New York are being shaped by the history of immigration among whites, by the predominance of ethnic minorities in the city's population and institutions today, and by the

Paper presented at the conference on "Host Societies and Reception of Immigrants: Institutions, Markets and Policies," Weatherhead Center for International Affairs, Harvard University, May 10-12, 2001. We wish to thank the Russell Sage Foundation, the Andrew W. Mellon Foundation, the Ford Foundation, the Rockefeller Foundation, the UJA-Federation of New York and the National Institute of Child Health and Human Development for their generous support. We also thank Jennifer Holdaway, Michelle Ronda and Aviva Zeltzer-Zubida for their assistance. 
interaction among immigrant and native minority groups, not the interaction between immigrants and some core group of white Americans. We ask the reader to think not only about the social distances that immigrants must travel from their countries of origin to become integrated into American society, but the changing nature of the society which they are joining. Thinking along these lines, we argue, requires us to challenge and revise certain key aspects of the theory of segmented assimilation.

Our larger project asks how the contexts in which young second generation immigrants have grown up in New York have affected their experiences in school and on the job, how they feel about their progress, and where they think they fit within American society. Here, we focus on the ways in which it matters a great deal that young second generation people are growing up in a city with a long history of immigration for all groups - including whites and blacks as well as Latinos and Asians. (The implicit contrast, of course, is with Los Angeles, where the non-Hispanic white and black populations are overwhelmingly native stock.) Given that they come largely from non-European ethnic origins, we ask what it means to grow up in a "majority minority" city.

We base our conclusions on a large-scale study under way since 1999. It conducted telephone interviews with random samples of 3,424 men and women aged 18 to 32 living in New York City (except Staten Island) and the inner suburban areas of Nassau and Westchester counties and northeastern New Jersey, followed up with in-depth, in-person interviews with ten percent of these respondents. We chose them according to whether their parents were from China (including Taiwan, Hong Kong, and the Chinese diaspora), the Dominican Republic, the West Indies (including Jamaica, Trinidad, Barbados, and other English-speaking islands), and Guyana (but excluding Haiti and those of Indian origin), the South American countries of Colombia, Ecuador, and Peru (subsequently designated CEP), or Jewish immigrants from the former Soviet Union. These groups comprised 39 percent of the 1990 second generation population in the defined sample area. ${ }^{2}$ For comparative purposes, we also interviewed samples of native born people with native born parents from among whites, blacks, and Puerto Ricans. About two thirds of the immigrant second generation respondents were born in the United States, mostly in New York City, while one third were born abroad but arrived in the U.S. by age 12 and had lived here for at least ten years.

${ }^{2}$ To represent the full range of children of immigrants, we included people who were born abroad but arrived in the Unired States by age 12 and had lived here for ten or more years. To complete the Russian sample, we had to relax this requirement to arrival by age 18 . 
In 1999-2000 we also fielded six ethnographies targeted on institutions and sites where these second generation and native young people were likely to encounter each other, including a four-year college of the City University of New York (CUNY), a CUNY community college, a large public service employees union, a retail store, several Protestant churches, and community political organizations. Together, these data sources provide the best picture yet available of the life situations of a representative cross section of the major racial and ethnic groups in metropolitan New York. It is the first study based on a random sample of the adult children of immigrants who arrived in the United States after 1965.3

After outlining the main contours of the school and work outcomes of the different second generation groups, we address the question of what it means for them to come of age in a heavily non-white, heavily immigrant context. We take issue with some of the assertions of the theory of segmented assimilation, arguing that it has an unsophisticated model of intergroup contact, conflict, and discrimination. That theory also does not take into account the ways that institutions that promote minority advancement also facilitate the incorporation of the second generation, including mainstream as well as minority institutions. Finally, we argue that the dominance of those who are not non-Hispanic whites among our age group (where non-Hispanic whites make up only about a quarter of the population) means that immigrant and native minority young people are creating a vibrant youth culture that is neither "immigrant" nor "middle American," but rather something new. The previous literature has failed to appreciate the importance of this development. We conclude that simple theories about assimilation, whether of the old-fashioned "straight line" or new "segmented" varieties fail to capture the complexity of the ways in which our respondents are becoming "New Yorkers." As New Yorkers, they are forging identities that differ strongly from that of their parents' country of origin, but also differ from those of mainstream white or black Americans.

3Portes and Rumbaut (2001) have completed several waves of the Children of Immigrants Longitudinal Survey (CILS) in San Diego and Miami, drawing initially on a school-based sample. Surveys like CILS and our own are necessary because the Census Bureau decided to drop the census question about birthplace of parents in favor of a subjective question on ancestry just as the new second generation began to grow rapidly in the 1970 s and 1980s. As a result, the second generation disappeared statistically into the native minority population, preventing us from tracking their progress, particularly after leaving their parents' homes. In 1994, the Current Population Survey added a question about parents' birthplace that now allows researchers to examine the second generation for a national sample, but the CPS does not contain enough respondents for many types of analysis, nor does it ask about many domains that are critical to immigrant incorporation. 


\section{IMMIGRATION TO NEW YORK}

Immigration has profoundly transformed the population of metropolitan New York, just as it has those of other gateway cities like Los Angeles or Miami. About ten percent of the 900,000 legal immigrants and refugees who arrive in the United States every year settle in New York City proper. The foreign born now make up 36 percent of the city's population and the second generation another quarter. Native born whites with native born parents make up only 18 percent of the city's population. In short, New York City is overwhelmingly a city of minorities and immigrants. Moreover, New York's immigrant stock population is far more diverse in racial and ethnic terms than those of other cities. Unlike its main rival, Los Angeles, where Mexicans alone comprise 40 percent of the immigrant population (Zhou, 2001:215), New York receives immigrants from all of the world's sending regions including Europe and the Caribbean as well as Latin America and Asia. As Table 1 shows, the native children born to two immigrant parents living in New York City are less likely to be Hispanic than in Los Angeles County, the other gateway cities (San Francisco, Chicago, Houston, Miami) or the country as a whole, though New York is still home to many Hispanic second generation people. The Asian and non-Hispanic white shares of its second generation resemble those of the nation as a whole, while New York also has a large black second generation. Note that Table 1 shows that New York is home to many white children of immigrants, unlike Los Angeles County. For fiscal year 2000, the Immigration and Naturalization Service reports that the top ten countries sending immigrants to New York City (a total of 85,000) were the Dominican Republic, China, Jamaica, Haiti, the Ukraine, Bangladesh, Pakistan, Ecuador, India, and Russia (INS, 2001:Table 18).

The large flow of black and Latino immigrants into New York has strongly affected the city's traditional "minority" groups. In 2000, the foreign born and their children constituted more than half of all blacks and Hispanics and virtually all of the Asian population in the city (Mollenkopf, Olson

TABLE 1

Racial Composition of Second Generation Bx City (VERTICAL PERCENT DISTRIBUTION)

\begin{tabular}{lcccc}
\hline \hline & Hispanic & NH Asian & NH Black & NH White \\
\hline New York City & 30.0 & 13.2 & 20.7 & 36.1 \\
LA County & 74.5 & 13.1 & 1.1 & 11.3 \\
Gateway Central Cities & 51.0 & 23.9 & 2.6 & 22.4 \\
U.S. Total & 43.0 & 14.3 & 4.2 & 38.5 \\
\hline
\end{tabular}


and Ross, 2001:Table 1.5). Of course, this is a tradition in New York. Between 1892 and 1924, thousands of European immigrants arrived at Ellis Island every day. In 1910, two out of five New Yorkers were born abroad, mostly in Europe, but also including many West Indians. In 1920, a quarter of the city's black population was West Indian (Kasinitz, 1992:24-25). Thus, both the white and black residents of New York have a strong immigrant tradition. We will argue that this crucially shaped the ways in which mainstream and minority institutions have reacted to new immigrants, making the city porous and welcoming even to new immigrants from previously unrepresented groups.

Mollenkopf (1999) has noted that the impact of immigration on the city's population and its self-conscious position as America's quintessential immigrant destination have shaped New York's culture, economy, and political structure. Waldinger (1996) has outlined patterns of ethnic succession in the city's economy that have been paralleled in its politics (Foner, 2000; Mollenkopf, Olson, and Ross, 2001). Irish and German immigrants began to challenge New York's Anglo Saxon Protestant elite in the 1860s and 1870s, followed by Italian and Central European Jewish immigrants at the turn of the century.

Beginning in the 1960s, the rapid growth of the city's black and Puerto Rican populations in the previous decades resulted in growing minority activism, culminating in political alignments. Today, as Mollenkopf (2000:419) writes, "In New York, white Protestants are practically invisible, if still economically and socially powerful. Instead the city's white population is dominated by first, second and third generation Catholics and Jews. Far from finding intergroup competition threatening, they are masters of the art." In short, when new immigrants and their children encounter whire - or black - Americans in New York, they do so along an ethnic continuum, not across a sharp boundary between nonwhite immigrants and native whites, as they do in Southern California, Texas, or Florida.

\section{SCHOOL AND WORK}

Among our respondents, as might be expected, the native whites, Russian Jews, and Chinese are significantly more likely to have completed a four-year college or to have attended post-graduate education than the other groups and significantly less likely to have dropped out of high school. Table 2 shows these outcomes for the older members of our sample, who have had time to complete their educations. On this score, Puerto Ricans are faring the worst, with Dominicans, native blacks, and the CEP countries also having relatively high dropout rates and low college graduation rates. The general pattern is 
that Latinos do worst and blacks only slightly better, while the Chinese, Russians, and whites do best. Within those broad groupings, the second generation groups are somewhat more successful than their native born counterparts. This underlying pattern becomes even stronger after controlling for parents' education, gender, and age, in part because the parents of Puerto Ricans have somewhat higher levels of education than those of the Dominican and CEP second generations, while the education levels among parents of the Chinese and Russian second generations are not as high as those among the native white parents (Mollenkopf, Kasinitz and Waters, 2001).

TABLE 2

EDUCATIONAL ATTAINMENT By Group

(AGED 24-32)

\begin{tabular}{|c|c|c|c|c|c|c|c|c|}
\hline & CEP & Domin & $\begin{array}{l}\text { Puerto } \\
\text { Rican }\end{array}$ & $\begin{array}{l}\text { West } \\
\text { Indian }\end{array}$ & $\begin{array}{l}\text { Native } \\
\text { Black }\end{array}$ & Chinese & Russian & $\begin{array}{l}\text { Native } \\
\text { White }\end{array}$ \\
\hline High school dropout & 10.1 & 12.4 & 19.6 & 3.5 & 12.8 & .5 & 1.8 & 3.7 \\
\hline Still in high school & .5 & 1.1 & 1.4 & .6 & .7 & & & .4 \\
\hline GED & 3.2 & 2.3 & 3.7 & 2.3 & 4.4 & .5 & .9 & 1.1 \\
\hline High school grad & 14.4 & 11.9 & 19.6 & 12.3 & 19.0 & 4.1 & 6.3 & 9.2 \\
\hline In 2-year college & 3.2 & 4.5 & 2.7 & 7.0 & 2.9 & 2.3 & 1.8 & 1.1 \\
\hline Some college, no degree & 26.6 & 21.5 & 26.9 & 22.8 & 31.0 & 11.7 & 10.8 & 9.9 \\
\hline 2-year college grad & 5.3 & 9.6 & 3.2 & 9.4 & 4.0 & 2.3 & 4.5 & 5.5 \\
\hline In 4-year college & 8.5 & 6.8 & 6.8 & 9.4 & 5.8 & 9.0 & 10.8 & 1.8 \\
\hline 4-year college grad & 19.7 & 20.9 & 10.0 & 22.2 & 14.6 & 45.9 & 36.0 & 37.1 \\
\hline In $\mathrm{grad} /$ prof school & 5.9 & 4.5 & 3.7 & 7.0 & 2.9 & 12.6 & 6.3 & 11.4 \\
\hline Some grad, no degree & .5 & 1.7 & 1.4 & & .7 & 2.3 & .9 & 4.0 \\
\hline Grad or prof degree & 2.1 & 2.8 & .9 & 3.5 & 1.1 & 9.0 & 19.8 & 14.7 \\
\hline
\end{tabular}

Refining this analysis, it is also apparent that those of our respondents who do attend a four year college attend institutions that systematically vary in quality as indicated by U.S. News and World Report college rankings. ${ }^{4}$ In our sample, 23 percent of the Chinese, 16 percent of Russian Jews and 38 percent of native whites attended "national tier one" colleges - compared to only 6 percent of native African Americans, 8 percent of Puerto Ricans, 7 percent of Dominicans, and 7 percent of West Indians. By contrast, 22 percent of college-educated Dominicans, 38 percent of native African Americans, 35 percent of Puerto Ricans and 39 percent of West Indians had gone to "region-

4We use an eight point scale: national 1,2,3 and 4 and regional 1,2,3 and 4. National colleges and universities recruit students from across the country, with one being the most selective and four the least. Regional schools recruit from local areas, again with one being the most selective and four the least. National one schools include Harvard, Yale, Columbia and NYU, while the regional fours include the least selective of the CUNY schools, such as York College, Medgar Evers and Lehman, as well as private institutions like Pace. 
al tier four" schools - as opposed to 4 percent of Chinese and 9 percent of the Russian Jewish respondents. Thus, not only the quantity but also the quality of education varies grearly across our groups of respondents.

We also compared the occupation and industry profile of our second generation respondents with those of their parents and the city as a whole. As one might suspect, the parents of our second generation respondents were highly concentrated in ethnic "niche" occupations and segmented by gender. Two out of every five fathers of our Chinese respondents worked in restaurants, while more than a third of the mothers of our West Indian respondents are nurses or nurses' aides. New York's beleaguered manufacturing sector continues to play an important role for immigrants, particularly for those immigrant women who (unlike West Indians) do not speak English upon arrival. Forty-six percent of the mothers of our Dominican respondents, 43 percent of the CEP mothers, and a staggering 57 percent of the Chinese mothers worked in manufacturing, primarily in the garment industry.

Our second generation respondents depart strongly from this pattern. They are markedly less occupationally concentrated than their parents and their occupational distributions resemble each other and those of all New Yorkers their age and gender. For example, only 3 percent of the male Chinese respondents worked in restaurants, while 9 percent of West Indian female respondents worked as nurses or nurses' aides. This is a much higher percentage than for any other second generation group, but still far lower than that of their mothers. While greater economic opportunity has pushed the second generation away from their parents' jobs, they also have a distaste for stereotypical "ethnic" occupations. When asked what job he would never take, one of our Chinese in-depth respondents replied, "delivering Chinese food." When the daughter of the Chinatown jewelry shop owner was asked if her father would like her to take over the business, she laughingly replied, "no, he doesn't hate me that much!" Even less successful groups have exited from parental niches. There is a striking drop-off in manufacturing employment between the generations. While manufacturing is an important employer of fathers, and particularly mothers, for all second generation groups except West Indians (including Puerto Ricans), second generation employment in manufacturing drops below that of the general population of the study area. As one Colombian respondent put it when asked if he would consider taking his father's job "Hey, I don't do that factory thing."

What do they do? Many have been attracted to New York's large Finance, Insurance and Real Estate (FIRE) sector. Indeed, Chinese and Rus- 
sian respondents are more likely to work in this sector than native whites or New York City residents as a whole. The sector also employs many CEP respondents. Interestingly, FIRE sector employment is higher among the second generation than their parents in every group except West Indians. For the most part, however, second generation respondents report working at the same kinds of jobs most young people get. Given their age and the era in which they entered the labor market, retailing and clerical work are the first or second most common occupation for every group except native whites, where they are the second and third most common.

Some interesting ethnic particularities in the occupational distribution suggest that some new "ethnic niches" may be forming: Chinese work in finance and as computer and design specialists; the Russians specialize in work with computers; Dominicans, the CEP, and Puerto Ricans are often financial clerks; West Indians work in health care; and native whites work in media and entertainment. The overwhelming story is nevertheless one of similarity rather than recapitulating the group differences evident among their parents. Our education and occupation data show some evidence of downward mobility for Puerto Ricans, somewhat stronger occupational differentiation for West Indians, and significant upward mobility for the Chinese second generation. But the second generation are going to school and working with each other and most do not show any signs of the second generation decline that distressed some analysts at the beginning of the 1990s (Gans, 1992; Portes and Zhou, 1993).

\section{INTERGROUP CONTACT AND CONFLICT}

Because minority and second generation immigrant young people dominate their age cohort, our respondents have a great deal of contact with each other, but sometimes have little contact with native white New Yorkers. Recalling their experiences of discrimination in the multiethnic worlds in which they grew up, members of the second generation often found themselves at odds not with whites but with other nearby groups. While the second generation is on average less concentrated in immigrant neighborhoods than their parents, many still live in such areas. The 2000 Census data show that first generation West Indians are the most highly segregated, living in central Brooklyn, southeast Queens, and the north Bronx in New York as well as Hempstead, Long Island, and Jersey City, New Jersey. Dominicans remain heavily concentrated in Washington Heights, with lesser concentrations on Manhattan's Lower East Side, Sunset Park and Bushwick in Brooklyn, and Elmhurst 
and Jackson Heights in Queens. While many Chinese immigrants still live in Manhattan's Chinatown, Chinese residents, especially the second generation, are spreading through South Brooklyn and Corona, Elmhurst and Flushing in Queens. The CEPs mostly live in Queens and in Jersey City. Russian Jews are concentrated in the Brighton Beach section of Brooklyn.

The responses that our survey and follow-up interviews gave to a series of questions about experiences of prejudice and discrimination are summarized in Table 3. As we might expect, blacks and West Indians reported facing the highest levels of discrimination while shopping, from the police, or while looking for work or at work, with the Hispanic groups not far behind, and the Chinese, Russians, and whites experiencing the least discrimination in these realms. We were surprised at the high levels of prejudice that the Chinese reported experiencing in school - more than any other group. Our in depth interviews indicated that this experience did not stem from interactions with whites, but rather with African Americans. The Chinese also report a relatively high level of prejudice experienced in stores.

We also asked whether parents had ever talked with our respondents about discrimination against their group, as reported in Table 4. Three quarters of native blacks said that their parents had talked with them about dis-

TABLE 3

EXPerience of Prejudice by Group (Percent Experiencing Prejudice)

\begin{tabular}{lccccc}
\hline \hline & At work & $\begin{array}{c}\text { Shops } / \\
\text { Restaurants }\end{array}$ & $\begin{array}{c}\text { From } \\
\text { Police }\end{array}$ & At School & $\begin{array}{c}\text { Looking } \\
\text { for Work }\end{array}$ \\
\hline CEP & 20 & 41 & 22 & 17 & 17 \\
Dominican & 19 & 37 & 25 & 14 & 20 \\
Puerto Rican & 26 & 40 & 22 & 15 & 22 \\
West Indian & 30 & 57 & 35 & 17 & 26 \\
Black & 35 & 55 & 34 & 15 & 33 \\
Chinese & 14 & 41 & 13 & 25 & 12 \\
Russian Jew & 8 & 12 & 8 & 11 & 9 \\
White & 14 & 15 & 6 & 9 & 6 \\
Source: Second Generation Study & & & & &
\end{tabular}

crimination against their group. But a large proportion of Russian and Chinese respondents ( 66 percent and 60 percent, respectively) also report talking to their parents about discrimination. Even though the Russians and the Chinese are doing the best in terms of educational attainment and labor market outcomes, they are also the most likely to tell our in-depth interviewers spontaneously that discrimination has been an impediment to their success.

We can understand the variation in "paths of discrimination" as 
TABLE 4

Talked With Parents about Racism and Discrimination against Group (Percent SaYing Yes)

\begin{tabular}{ll}
\hline \hline Chinese & 61 \\
CEP & 44 \\
Dominican & 58 \\
Black & 77 \\
Puerto Rican & 58 \\
Russian Jew & 66 \\
West Indian & 54 \\
\hline Source: Second Generation Study &
\end{tabular}

Figure I. Prejudice/Discrimination

\begin{tabular}{|c|c|c|}
\hline $\boldsymbol{\nabla}$ & $\nabla$ & $\nabla$ \\
\hline $\begin{array}{l}\text { From Whites in Public } \\
\text { Spaces }\end{array}$ & $\begin{array}{l}\text { From Whites at } \\
\text { Work and School }\end{array}$ & $\begin{array}{l}\text { From Blacks and Puerto Ricans } \\
\text { in Public Spaces and School }\end{array}$ \\
\hline $\boldsymbol{\nabla}$ & $\boldsymbol{\nabla}$ & $\nabla$ \\
\hline Blacks and Hispanics & $\begin{array}{l}\text { Chinese, Upwardly } \\
\text { Mobile Blacks and Hispanics }\end{array}$ & $\begin{array}{l}\text { Chinese, Russians, West } \\
\text { Indians, Dominicans, CEP }\end{array}$ \\
\hline $\boldsymbol{\nabla}$ & $\boldsymbol{\nabla}$ & $\boldsymbol{\nabla}$ \\
\hline $\begin{array}{l}\text { Discouragement, Anger, } \\
\text { Reactive Ethnicity }\end{array}$ & Try Harder & Distancing, Stereotyping \\
\hline
\end{tabular}

responses to differing group opportunity sets, as outlined in Figure I. The indepth interviews reveal that native blacks and West Indians, as well as the Dominicans, Puerto Ricans, and some CEPs, report that whites often discriminate against them or show prejudice in public spaces such as streets, stores, and the like. These experiences include harassment by the police, "driving while black," whites moving across the street to avoid passing near them, and store clerks following them to make sure they do not shoplift. This treatment often resulted in the kinds of discouragement, anger, and reactive ethnicity that Portes and his colleagues identified in his theory of segmented assimilation.

In contrast to this "minority experience" in public settings, Chinese and the upwardly mobile blacks and Hispanics in our sample often met a more personal form of discrimination from whites while attending school or on the job. This "face to face" prejudice is more common for better-off respondents who leave their neighborhoods, shop in more upscale stores, and work in predominantly white settings. As a result, they are more likely to encounter, and 
compete with, native whites. These are the situations where parents warn their children that they can expect prejudice and should devise ways to cope with it. But in contrast to the anger and disengagement that often resulted from the experience of impersonal discrimination, many of these respondents reported that they believed they needed to try harder when encountering what was in effect a "glass ceiling." Instead of disengaging, they reacted with increased effort and a sustained focus on success.

Finally, given that native whites constitute a small minority in New York City, it is not surprising many members of the second generation report encounters with other immigrant and minority group members that involved conflict, prejudice, and discrimination. They often reacted to this type of conflict with distancing behaviors, as when West Indians try to distance themselves from African Americans or Dominicans seek to distinguish themselves from Puerto Ricans, or when Chinese and Russians distance themselves from blacks and Latinos from various backgrounds.

\section{REASSESSING SEGMENTED ASSIMILATION}

In recent years, thoughtful observers have advanced the disturbing hypothesis that the new second generation will experience downward mobility as they are absorbed into the native black or Latino populations living in concentrated poverty neighborhoods. Gans (1992) outlines several scenarios in which the children of the new immigrants could do worse than their parents or most others their age. He speculates that second generation immigrants who go to low performing inner city schools, get bad jobs, and enter shrinking economic niches will experience downward mobility.

Drawing on ethnographic case studies and the CILS survey of second generation school children in Miami and San Diego, Portes and Zhou (1993) refine this approach by arguing that the differing modes of incorporation in the first generation endow their children with differing amounts of cultural and social capital (ethnic networks and values) and different opportunity structures, resulting in several distinct paths toward incorporation. Those who live among American blacks or Latinos and face racial discrimination will, in their view, adopt a "reactive" native minority ethnicity. But those who come from groups with strong ethnic networks, access to capital, and fewer ties to U.S. minorities will, they postulate, follow one of two other paths: the "linear ethnicity" of assimilation into a native white ethnic category, or "segmented assimilation" into a retained immigrant identity that distinguishes them from American blacks or Puerto Ricans/Chicanos. 
As for Gans, the fundamental point for Portes and Zhou (1993) is that second generation young people who cast their lot with America's minority groups, whose peer culture supposedly rejects success at school and work, will experience downward social mobility. This dynamic inverts the normal model of acculturation: when "becoming American" for the children of brown and black immigrants means embracing the values of their native ghetto peers rather than their immigrant parents, they will suffer for it. They will embrace American definitions of status and success, but, according to this view, they will also be loath to accept the poorly paid jobs held by their immigrant parents. They will disconnect from opportunities within ethnic economy, but racial discrimination within the mainstream economy will limit their alternatives, fostering an "oppositional" identity, becoming rebellious, or questioning the value of education.

Our study suggests that this model holds a far too negative stereotype of native minorities and the supposed self-defeating role model they provide for second generation immigrants. Since much of the research on segmented assimilation fails to include comparisons with native whites, blacks, or Latinos, it fails to appreciate either the full range of experience within these groups - much of which is quite successful - or the fact that whites as well as minorities engage in oppositional behaviors. A case in point involves the arrest rates among males in our study, presented in Table 5. The arrest rate for native whites surpasses that of every second generation group except for West Indians. But getting arrested apparently does not have the same lasting negative consequence for whites that it does for those who are branded by negative racial stereotypes or whose families have fewer resources to help them overcome yourhful mistakes. In other words, the key factor is not a group trait but a societal response. White youth often exhibited oppositional behaviors and made mistakes, but they typically were able to recover from the same behaviors that left members of minority groups at a lasting disadvantage. Thus, the theory of segmented assimila-

TABLE 5

ARRest by Group (Males)

(Percent Ever Arrested)

\begin{tabular}{lcc}
\hline \hline & No & Yes \\
\hline CEP & 79.8 & 20.2 \\
Dominican & 78.4 & 21.6 \\
Puerto Rican & 70.9 & 29.1 \\
West Indian & 75.5 & 24.5 \\
Native Black & 65.8 & 34.2 \\
Chinese & 90.2 & 9.8 \\
Russian & 89.6 & 10.4 \\
Native White & 76.9 & 23.1 \\
\hline
\end{tabular}

Source: Second Generation Study 
tion needs to pay more attention to the consequences of behaviors and beliefs, not their existence alone.

\section{THE UNANTICIPATED POSITIVE IMPACT OF INSTITUTIONS OF MINORITY MOBILITY}

While the segmented assimilation model sees assimilation into native minority status as a path toward downward mobility, our study reveals that being classified as a native minority can also provide access to institutional supports that promote success. The civil rights movement, along with the minority advancement in mainstream institutions, has created a legacy of opportunity for new members of old minority groups. The struggle for minority empowerment has established new entry points into mainstream institutions and created many new minority-run institutions. By operating in contexts where "American" means African American or Puerto Rican, our respondents have developed ethnic solidarity with native blacks or Latinos and receive signals that they will be easily accepted into "America." This dynamic also puts native blacks and Puerto Ricans in the strange position of managing the ethnic succession of second generation individuals in colleges, labor unions, and political groups while continuing to see themselves as outsiders to these power structures. While community-based social services or affirmative action "second chance" entry points into white institutions were initially set up to aid blacks and Puerto Ricans, new second generation immigrants are well situated to take advantage of them.

Two tales from our ethnographies illustrate this point. One involves a Puerto Rican studies class at a community college in Queens. Founded in the late $1960 \mathrm{~s}$ in the first wave of open admissions to CUNY, this college was designed to be particularly sensitive to New York City's Hispanic population, then overwhelmingly Puerto Rican. This class, which met the college's American studies requirement, was taught by a Cuban American professor to students who were all Colombian, Ecuadorian, Peruvian, or Dominican. In other words, an immigrant professor was using the Puerto Rican experience to teach first and second generation Latino immigrants what it means to be American (Trillo, forthcoming).

Another ethnographer studied a public employee union that had been founded in the 1960s by Jewish radicals for a largely African American membership with origins mostly in the American south. Today, its leaders are mostly African Americans who rose through the civil rights movement, but the rank and file has become overwhelmingly first and second generation West Indians. 
At a union meeting celebrating its members' Caribbean heritage, they shouted out recognition for each of the various islands. Listening to this response, the African American union leader asked plaintively, "Isn't anyone here from Alabama?" (Foerster, forthcoming).

These stories illustrate the enormous significance of racial and ethnic succession within the city's institutions. Originally designed as agencies of advancement for native minorities, this community college and social service union are now "Americanizing" and "ethnicizing" immigrants and their children. In quite practical material, as well as symbolic, terms, they are promoting upward mobility - through skills, credentials, and financial support. As they make educational progress, especially compared to native blacks and Puerto Ricans, second generation West Indians, Dominicans and CEPs are well positioned to inherit leadership positions within minority institutions and gain greater access to mainstream institutions. We thus posit that becoming identified as a member of a racial minority can have tangible benefits for second generation New Yorkers. Segmented assimilation theory posits that this heralds downward mobility due to the negative influences of native minority peers. This misses both the fact that native minority young people are not alone acting out in negative ways - which may be endemic to the age group - and the fact that native minorities also provide positive role models and indeed access to minority and mainstream institutions that promote minority upward mobility.

\section{CREATING HYBRID MINORITY CULTURES}

We have noted that members of the second generation interact a lot more with each another and native minorities than with native whites, with important consequences for the patterns of prejudice and intergroup conflict experienced by different groups. But this intergroup contact also has positive dimensions. They are creating a new kind of multiculturalism, not of balkanized groups huddled within their own enclaves, but of hybrids and fluid exchanges across group boundaries. The city abounds in clubs where African American hip hop has been fused with East Indian and West Indian influences into new musical forms, for example. The real action is not in the interplay of immigrant cultures with a homogenous dominant American culture, but in the interactions between first and second generation immigrant groups and native minorities. African American young people dance to Jamaican dance hall and imitate Jamaican patois, even as West Indian youngsters learn African American slang. Puerto Ricans can meringue and Dominicans can play salsa and rap in two languages. Second generation youth growing up in 
an Indian/South American/Irish/Pakistani neighborhood like Jackson Heights, Queens, or in a Puerto Rican/Mexican/Chinese/Arabic neighborhood like Sunset Park (where the aged population of "real Americans" are Norwegians) do see themselves as Americans and New Yorkers, but they are not assimilating into the mainstream typical in, for example, Iowa. (Indeed, even in Iowa, Mexican workers have moved into the meatpacking industry.) Whether one looks at the music in dance clubs, the eclectic menus in restaurants, or the inventive slang on the streets, one cannot help but be impressed by the creative potential that second generation and minority young people are contributing to New York today.

This is reflected in how our respondents identify themselves. They used the term American in two different ways. One was to describe themselves as American compared to the culture, values, and behaviors of their parents. (For example, they were not inclined to endorse physical punishment of children.) They definitely thought that the U.S. had influenced them to approach the world differently from their parents. But they also used "American" to refer to the native whites they encountered at school, the office, or in public places, but whom they knew far better from television and the movies. They saw those "Americans" as part of a different that would never include them because of their race/ethnicity.

Many respondents sidestepped this ambivalent understanding of the term "American" by describing themselves as "New Yorkers." This was open to them even as blacks or Hispanics or Asians, and it embraced them as second generation immigrants. A "New York" identity embraced the dynamic cultural activities familiar to them, but not necessarily the larger white society. "New Yorkers," for our respondents, could come from immigrant groups, native minority groups, or be Italians, Irish, Jews, or the like. We argue that the individual changes necessary to become a New Yorker are not nearly so large as those required to become American. As immigration continues to transform our nation, New York may serve as a positive model of creative multiculturalism and inclusion. Whether other parts of America can replicate that openness remains to be seen. While some skeptics might argue that New York is very unique and not likely to be replicated in many other places, we would counterargue that, being quintessentially an immigrant city, New York is in fact at its very core American.

\section{REFERENCES}

Foerster, A.

Forthcoming “Isn't Anyone Here from Alabama? Solidarity and Struggle in a Mighty Mighty Union." In Becoming New Yorkers: The Second Generation in a Global City. Ed. P. Kasinitz, J. Mollenkopf and M. Waters. Under review. Russell Sage Foundation Press. 
Foner, $\mathrm{N}$.

2000 From Ellis Island to JFK: New York's Two Great Waves of Immigration. New Haven and New York: Yale University Press and Russell Sage Foundation Press.

Gans, $\mathrm{H}$.

1992 "Second Generation Decline: Scenarios for the Economic and Ethnic Futures of the post-1965 American Immigrants," Ethnic and Racial Studies, 15(2):173-193.

Kasinitz, P.

1992 Caribbean New York: Black Immigrants and the Politics of Race. Ithaca: Cornell University Press.

Mollenkopf, J. H.

2000 "Assimilating Immigrants in Amsterdam: A Perspective from New York," The Netherlands Journal of Social Sciences, 26(2):126-145.

1999 "Urban Political Conflicts and Alliances: New York and Los Angeles Compared." In The Handbook of International Immigration: The American Experience. Ed. C. Hirschman, P. Kasinitz and J. DeWind. New York: Russell Sage Foundation.

Mollenkopf, J. H., T. Ross and D. Olson

2001 "Immigrant Political Participation in New York and Los Angeles." In Governing American Cities: Inter-Ethnic Coalitions, Competition, and Conflict. Russell Sage Foundation.

Mollenkopf, J., P. Kasinitz and M. Waters

Forthcoming "Chutes and Ladders: Educational Attainment among Young Second Generation and Native New Yorkers." In The New Immigration and New York City: Essays on Employment, Education, Health and Public Policy. Ed. D. R. Howell.

Portes, A. and M. Zhou

1993 "The New Second Generation: Segmented Assimilation and its Variants," The Annals of the American Academy of Political and Social Science, 530:74-97.

1992 "Gaining the Upper Hand: Economic Mobility Among Immigrant and Domestic Minorities," Ethnic and Racial Studies, 15(4):491-521.

Portes, A. and R. Rumbaut

2000 Legacies: The Story of the New Second Generation. Berkeley: University of California Press.

Smith, J. and B. Edmonston

1997 The New Americans: Economic, Demographic, and Fiscal Effects of Immigration. Washington: National Academy Press.

Trillo, A.

Forthcoming "Pan Ethnicity and Educational Trajectories among Latino Community College Students." In Becoming New Yorkers: The Second Generation in a Global City. Ed. P. Kasinitz, J. Mollenkopf and M. Waters. Under review. Russell Sage Foundation Press.

Waldinger, $\mathrm{R}$.

1996 Still the Promised City?: African Americans and New Immigrants in Postindustrial New York. Cambridge: Harvard University Press.

Waters, M. C.

1999 Black Identities: West Indian Dreams and American Realities. New York: Russell Sage Foundation. 
Zhou, M,

2000 "Contemporary Immigration and the Dynamics of Race and Ethnicity." In America Becoming: Racial Trends and their Consequences. Ed. N. Smelser, W. J. Wilson and F. Mitchell. Washington, DC: National Academy Press.

1997 "Growing Up American: The Challenge Confronting Immigrant Children and Children of Immigrants." Annual Review of Sociology, 23:69-95. 